\title{
THE RELATIONSHIP BETWEEN RISK FACTOR AND EARLY DETECTION OF BREAST CANCER AMONG FERTILE WOMEN
}

\author{
Yuli Kusumawati, Tutyan Miasari \\ Public Health Department, Faculty of Health Science, Muhammadiyah University of \\ Surakarta, Surakarta
}

\begin{abstract}
Background: Breast cancer is the most common cancer in women, $10 \%$ of all women in the world suffer from breast cancer in her life. The pathophysiology of breast cancer is very slow in dozens or even decades. However in theearly stage,breast cancer can be identified by early detection and treatment so that strived for cancer deaths are still preventable.

Method: This study aimed to determine the relationship between family history, cigarette exposure, and the use of oral contraceptives and the action of early detection of breast cancer in fertile women ofThis study was an observational study used cross sectional design. The population was all women of childbearing age in Dawung Village Subdistrict Kebakkramat Karanganyar. Sample size was 88 taken by simple random sampling method. Data analysis was using the Fisher Exact test.

Results: The results showed that there was no correlation between family history of breast cancer, use of oral contraceptives with early detection of breast cancer. While cigarette exposure showed correlation with early detection of breast cancer.

Conclusion: It is recommended to women as well as their family to seek information regarding the risks and early detection of breast cancer. The detection can be done at least once in a month after menstruation, although it does not include high risk.
\end{abstract}

Keywords: cancer history in family, cigarette exposure, oral contraception, early detection of breast cancer.

\section{Introduction}

Currently, cancer is one of serious health problems, because the disease causes a lot of misery to the death. Cancer ranks second cause of death after heart disease. ${ }^{1}$ In America, there was at least 178.000 women suffer from breast cancer in $2008 .^{2}$ According to the results of Basic Health Research 2012, in Indonesia, the prevalence of cancer in the city tend to be higher than in the village, where the case proportion in women was higher than in men. ${ }^{3}$

According to $\mathrm{WHO}$, breast cancer is the most common cancer in women, $10 \%$ of all women in the world suffer from breast cancer in her life. The prevalence of breast cancer is increased by aging process, as many as 400 new cases of 100.000 cases occur each year. ${ }^{4}$ In Indonesia, there are an estimated 100 new cases per 100.000 population every year. This indicates that of the total 237 million population, there will be approximately 237.000 new cancer patients each year, and empirical data also shows that the deaths related to cancer from year to year continues to increase.

The prevalence of breast cancer in Central Java also increased from $0.02 \%$ in 2005 to $0.04 \%$ in 2006. In 2007, it was the same with those in 2006 that was $0.04 \%$, then increased again in 2008 that was $0.05 \%$. According to Basic Health Research in 2012, the prevalence of cancer in Central Java was the second place following DIY, 2.1 per mile.

The pathophysiology of breast cancer is very slow in dozens or even decades. The early symptoms of breast cancer are often not recognized or perceived clearly by people, hence so many people often come for treatment in an advanced 
stage. This has led to high rates of cancer mortality. To be date, in the early stages, cancer can be prevented in causing death. However, the symptoms which can be felt or seen by patients will not appear until the cancer has developed quite extensive and cannot be stopped by simple ways. ${ }^{2}$

The main effort to prevent breast cancer is avoid the risk factors and conduct early detection of breast condition. In that circumstance a woman has to be able to recognize the early changes of organs hence breast cancer can be identified early before entering an advanced stage. Based on the research results conducted by Firmaneni, Malini and Jamil (2007), it was found that the majority of women whodiagnosed with advanced breast cancer thought that a lump in their breast was common thing when they found them at first time. ${ }^{5}$ Causative factors in women with advanced breast cancer were late to go to hospital, less knowledge $(71.43 \%)$ related symptoms, early checkup and when to manage early checkup. In terms of attitudes in the early detection, there were nearly $100 \%$ of those who suffer from advanced stages have a negative attitude.

Meanwhile, secondary prevention by screening or early detection, is considered as the most rational effort to reduce the number of death from breast cancer. This screening study was first conducted by the Health Insurance Plan of Greater New York in 1963, the results were able to reduce the mortality rate between 20 to 25 per cent in the age group over 50 years. The screening examination consisted of clinical breast assessment by a health professional, for example, surgical specialists, doctor, trained nurses, checkup or mammography and the most important is breast self-examination (SADARI).

Based on the above reasons, the efforts to increase the knowledge women of childbearing age couples in order to prevent the occurrence of advanced breast cancer and the prevalence of existing look, there is a need a study to determine the relationship between knowledge Inthe early detection of breast cancer. Knowledge of fertile women become important because it will have an impact on a broad scale that will raise awareness among fertile women in improving their own health. Breast cancer is a disease that can be detected inthe beginning, therefore fertile women have to improve the knowledge about breast cancer in the early detection of breast cancer.

Early detection of cancer is an attempt to find the cancer has not been grown, still young, still local, and not cause significant damage therefore they can be cured. ${ }^{6}$ Early detection is usually performed on people who are "apparently healthy, asymptomatic, or in people who are at high risk of suffering from cancer. How early detection of breast cancer include: breast self-examination, breast examination by health professional workers and mammography.

The results of a preliminary survey of 10 fertile women in Dawung village, Kebakkramat distric Karanganyar of breast cancer is known that of the 10 women as much as $90 \%$ reported that they were afraid when they hear about cancer. Cancer is a hereditary, preventable diseases, $70 \%$ are early signs lumps breast pain, $50 \%$ said that they felt pain in the breast, $40 \%$ suspicious of pain in the breast, and $20 \%$ checkup to health professionals and $40 \%$ never heard the word "Sadari". Based on the results of the preliminary study, it is demonstrated that fertile women is fear of breast cancer, but they do not know how to detect early breast cancer that could be detected by the program checkup breast itseft "Sadari".

This study aims to determine the relationship between risk conditions about family history, exposure to smoke and the use oral contraceptives with the behavior of early detection of breast cancer at the fertile women in Dawung village, Kebakkramat distric Karanganyar. 


\section{Method}

This research wasan observational study with a descriptive analytic method, and using a cross-sectional design. The populationin this study were all women of childbearing age couples aged 19-45 years who live in the Dawung village, Kebakkramat District, Karanganyar as many as 113 people. The sample as many as 88 people were selected by simple random sampling. The data was collected through interviews using a structured questionnaire instrument. Data processing was done in some steps such as editing, coding, entry and tabulating. Data analysis includedunivariateanalysis, that was to describe each variable in the form of tables. Furthermore, bivariate analysis for hypothesis test used Fisher Exact test with a significance value of $5 \%$ used SPSS conducted in computer laboratory in Health Science Faculty of University of Muhammadiyah of Surakarta.

\section{Results and Discussion}

The results of analysis of participants characteristics which measured by age, gender and education are presented in Table 1.

Table 1. Characteristics of Eligible Women in Rural Dawung, Kebakkramat Karanganyar

\begin{tabular}{lc}
\hline Age & Age (years) \\
\hline Maksimal & 46 \\
Maximal & 21 \\
Average & 35.34 \\
\hline Education & $\mathbf{f}(\%)$ \\
\hline Basic & $12(13.6)$ \\
Junior high school & $10(11.4)$ \\
Senior high schoor & $41(46.6)$ \\
University & $25(28.4)$ \\
Total & $88(100.0)$ \\
\hline Job & $\mathbf{f}(\%)$ \\
\hline Private & $26(29.5)$ \\
Trade & $10(11.4)$ \\
Government employer & $14(15.9)$ \\
Housewife & $38(43.2)$ \\
Total & $88(100.0)$ \\
\hline
\end{tabular}

Based on Table 1 it can be seen that the average age of the respondents was 35.34 years old. The youngest and the oldest was 21 and 46 years old respectively. Based on the level of education, most respondents graduated from high school were as many as 41 (46.6\%), and the least were primary school as many as 10 people $(11.4 \%)$. Meanwhile, according to job, nearly half of participants were housewife, 38 people $(43.2 \%)$, while participants who work as traderswere at least as many as 10 people $(11.4 \%)$.

The results of the research on family history, cigatettesmoke exposure and oral contraceptives used in women of childbearing age in the village Dawung, District KebakkramatKaranganyar presented in Table 2. 
Tabel 2. Distribution of frequency of fertile women based on family history, smoking exposure andoral contraceptive usage in fertile women in the village Dawung, District

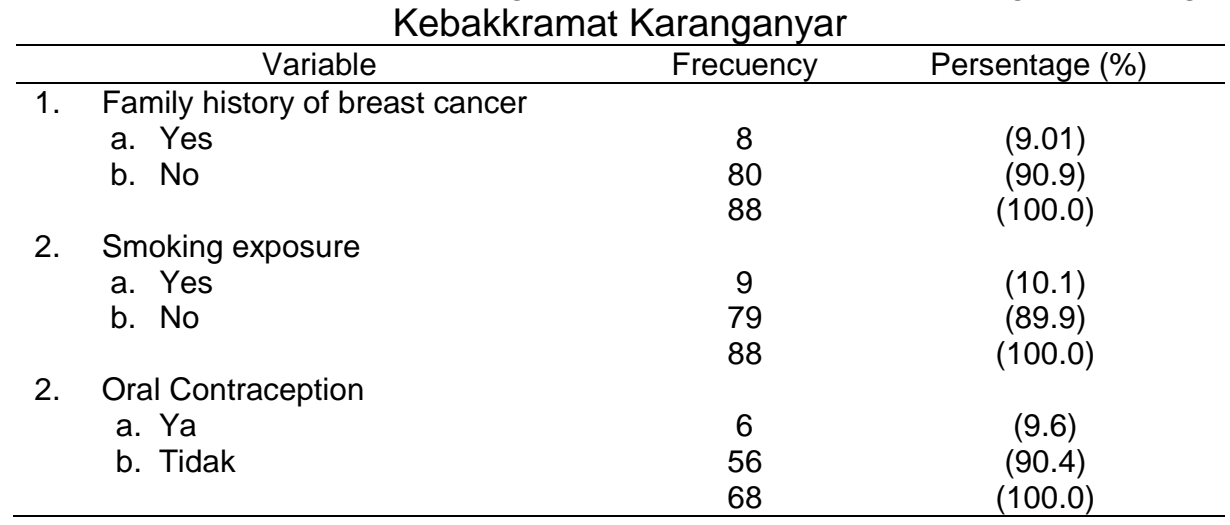

The following table shows the relationship between the risk factors consist of families with history of breast cancer, exposure to smoking and the use of oral contraception and the behavior of early detection of breast cancer by SADARI.

Table 3. The relationship between risk factors consist of Family History of Breast Cancer, Smoking exposure and oral contraception ued and Early Detection of Breast Cancer Behavior in the Dawung Village, Kebakkramat District of Karanganyar in 2013

\begin{tabular}{|c|c|c|c|c|}
\hline & \multicolumn{2}{|c|}{ Early Detection Behavior } & \multirow{2}{*}{ Jumlah } & \multirow{2}{*}{$P$ value } \\
\hline & Yes & No & & \\
\hline \multicolumn{5}{|c|}{$\begin{array}{l}\text { Family History of Breast } \\
\text { cancer }\end{array}$} \\
\hline Yes & $5(62.5 \%)$ & $3(37.5 \%)$ & $8(100 \%)$ & 0.283 \\
\hline No & $36(45.0 \%)$ & $44(55.0 \%)$ & $80(100 \%)$ & \\
\hline Total & 41 (46.6\%) & $47(53.4 \%)$ & $88(100 \%)$ & \\
\hline \multicolumn{5}{|c|}{ Smoking exposure } \\
\hline Yes & 8 (88.9\%) & $1 \quad(11.1 \%)$ & 9 (100\%) & 0.008 \\
\hline No & 33 (41.8\%) & 46 (58.2\%) & 79 (100\%) & \\
\hline Total & $41(46.6 \%)$ & $47(53.4 \%)$ & 88 (100\%) & \\
\hline \multicolumn{5}{|c|}{ Using Contraception } \\
\hline Yes & $29(48.3 \%)$ & $31(51.7 \%)$ & $60(100 \%)$ & \\
\hline No & $12(42.9 \%)$ & $16(57.1 \%)$ & $28(100 \%)$ & \\
\hline Total & $41(46.6 \%)$ & $47(53.4 \%)$ & $88(100 \%)$ & \\
\hline \multicolumn{5}{|c|}{ Oral Contraception } \\
\hline Yes & $3(50.0 \%)$ & $3(50.0 \%)$ & $6(100 \%)$ & 0.632 \\
\hline No & $26(27.9 \%)$ & $28(27.9 \%)$ & $54(100 \%)$ & \\
\hline Jumlah & $29(48.3 \%)$ & $31(51.7 \%)$ & $60(100 \%)$ & \\
\hline
\end{tabular}

Based on Table 3, it is noted that fertile women have a family history of breast cancer, early detection of breast cancer was done by five people (62.5\%), and women who did not manage early detection was slightly lower, that is as many as three people $(37.5 \%)$. Meanwhile, those who have no history of breast cancer, but conducted early detection was36 people (46.5\%).

It canbe seen that the tendency of the most of fertile women who smoking and did early detection of breast cancer is more than those who did not, that was 8 people $(88.9 \%)$ compare to one person only $(11.1 \%)$. However, more than a half of fertile 
women who were not smoking did not manage early detection of breast cancer that were 46 people $(58.2 \%)$.

In addition, it can be seen on Table 3, a tendency of women in reproductive age who using contraception were 60 people. It is highlighted that as many as 31 women $(51.7 \%)$ who used contraception did not manage early detection of breast cancer. Similarly, for those women who did not used contraception, it is reported that 16 women $(57.1 \%)$ did not perform early detection of breast cancer. Based on the type of contraception used by women, the majority contraception used was not oral contraception (pills). It is noted that there was the same number for women who used oral contraception (pill) and who did not in terms of performing early detection of breast cancer that were 3 women each (50\%).

Based on the results of statistical analysis using Fisher Exact test, it is known that there was no correlation between family history of breast cancer and the early detection of breast cancer behavior, the $p$-value $=0.283>0.05$. The test results with the relationship between exposure to smoking behavior of early detection of breast cancer obtained $p$-value $=0.008<0.05$, which indicates no relationship. While, the relationship between the useof oral contraceptive behavior and early detection of breast cancer showed $p$-value $=0.632>0.05$, therefore it is reasonable to conclude that there was no correlation.

\section{Discussion}

Fertile woman is a woman who ovulated to produce ovum every month, and menstruate if fertilization does not occur. If fertilization occurs, a woman will be pregnant, delivering birth after nine month of pregnancy, and the postnatal. This cycle will be experienced by every healthy woman. However, if a woman has health problems related to the reproductive organs, the reproductive period will be disrupted. One of the disorders in the reproductive organs is the formation of new tissue known as a tumor or breast cancer.

There is a number of literature reported that breast cancer can be cured if the case is known since the early stage and treated immediately. However, mostly patients come to health servicesthey are already in an advanced stage or severe of breast cancer. Therefore breast cancer is difficult to be cured, and that there is no hope for the life to be saved. That condition is caused by a lack of knowledge of a woman to recognize the early signs and symptoms of breast cancer.

The identification and recognition of the early signs and symptoms of breast cancer can be done by doing SADARI. In this study, the data was collected on 88 fertile women in the Dawungvillage, Kebakramat District Karanganyar. The average age of respondents was 35.34 years old. The youngest age was 21 years old and the oldest was 46 years old. This suggests that the age of all respondents are fertile women, and need to understand about the signs and symptoms of breast cancer as well as knowing the risk factors of breast cancer and early detection by SADARI.

Based on the level of education, the fertile women in the Dawungvillage have had education middle level, it can be seen from the baseline data that showed $46.6 \%$ women graduated from high school, and $43.5 \%$ participant working as housewife. Most of respondents had no family history of breast cancer was not smoking. Although most of participant used contraceptions, but the use of oral contraception (pill) was only 6 people (10\%). This suggests thatthe participant was at low risk group of breast cancer. Furthermore, results showed that cigarette smoke exposure as one of risk factorshad no correlation and the early detection behaviors of breast cancer ( $p$-value $=0.008$ ). This is possible because most women already knew the health information on cigarette advertisement "smoking may causes heart disease, cancer and pregnancy and fetal disturbance". Hence, fertile women in Dawung village who have been exposed to 
cigarette smoke did early detection of breast cancer. Although, in this study of a small number of women who are exposed to cigarette (smoking), almost all of them have early detection of breast cancer (88.9\%).

Meanwhile, finding showed that there is no relationship between the use of oral contraceptive and breast cancer early detection behaviors ( $p$-value $=0.632$ ). It is indicated that a woman who has breast cancer risk (e.g. using oral contraceptive) is not necessarily mean that she has behaviour to manage early detection. It was possibly because the participant did not feel at risk and did not know what the risk factors that allow for breast cancer to evolve, and that they thought that they did not need to be aware of early detection. The fertile women in the Dawung village also did not know that the use of oral contraceptives in a long term is a risk factor for breast cancer. They just want to use contraception to manage the number and birth spacing of their children in accordance with the instructions of health professionals. In addition, the participant choosed the type of contraception only based on their interest which suit them best.

In Miasari's study (2013), it is reported that 54\% women in the Dawung village have good knowledge about breast cancer, early detection, risk factors and the occurrence.Nevertheless, the behavior for the early detection of breast cancer was only $46.4 \%{ }^{7}$ Those findings is in accordance with the research conducted by Untari (2006) about the relationship between knowledge and attitudes and BSE (Breast Self Examination) behaviour on a women's group of Islamic religion called as Khairun-Nisa at Taman Sari Sragen. ${ }^{8}$ The results showed that there is a significant correlation between knowledge about BSE behavior. Good knowledge about breast cancer and BSE will support a woman to be aware of of breast cancerearly detection. However, if the lack of knowledge and understanding, even if they are at high risk of developing breast cancer, a woman will not necessarily perform early detection, primarily because health check-up requires a lot of costs. These results are compatible with the research conducted by Purwatiningsih (2009) which found that there was no correlation between knowledge about breast cancer and the motivation to doing breaset cancer early detection. $^{9}$

In terms of education factor, in this study, the majority of the education of participant was classified in middle education, that were 41 women graduated from high school (46.6\%). In that circumstance, the participant's knowledge was good. It is related to the research conducted by Handayani (2008) which shows that there was a significant association between level of education and knowledge fertile women, the higher the level of a person's education the more knowledge about BSE she has. ${ }^{10}$ There is a need for women to have awareness of early detection good knowledge about the disease, risk factors, and how to overcomethe health problems. If women have good knowledge of breast cancer early detection they will make good efforts to come to health care services, and that will not be late to address the problem.

\section{Conclusion and Recommendation}

This study concluded that there were no relationship between family history of breast cancer and oral contraceptive used and breast cancer early detection behaviors. While, cigarette smoke exposure has significant relationship with the behavior of early detection of breast cancer.It is recommended to women as well as community that they need to seek information about the risk and The detection can be done at least once in a month after menstruation, although it does not include high risk.In addition, it is very important for the health officer to enhance activities related to health promotion of breast cancer risk and how to conduct early detection of breast cancer to the public, hence community may take the best decision for their interest. 


\section{References}

1. Ghofar A., Cara Mudah Mengenal dan Mengobati Kanker, Yogyakarta: Flamingo, 2009.

2. Nurcahyo J., Awas!!! Bahasa Kanker Rahim dan Kanker Payudara (Mengenal, Mencegah, dan Mengobati Sejak Dini Dua Kanker Pembunuh Paling Ditakuti Wanita), Yogyakarta: Wahana Totalita Publisher, 2010.

3. Kemenkes, Riset Kesehatan Dasar, Jakarta: Kemenkes RI, 2012.

4. Hidayat B., Eko Purnomo, Husein Kartamihardja, Masjhur, Signifikansi dari Korelasi Uji Petanda Tumor CEA, CA-15,3 dengan Sidik Tulang pada Pasien Kanker Payudara, Jurnal IImu Kedokteran Nuklir, 2009.

5. Firmaneni dan Malini H., Identifikasi faktor-faktor Keterlambatan Mencari Pengobatan Medis Penderita Kanker Payudara Stadium Lanjut di IRNA Bedah RS Dr. M. Djamil Padang, Skripsi, PSIK, Padang: Unand, 2007.

6. Sukardjo IGD., Onkologi Klinik, Surabaya: Universitas Airlangga, 2000.

7. Miasari T, Faktor-faktor yang berhubungan dengan perilaku Deteksi Dini Kanker Payudara pada Wanita Usia Subur di Desa Dawung Kebakkramat Karanganyar, Skripsi, Surakarta: Universitas Muhammadiyah Surakarta, 2013.

8. Dwi Untari, Pemeriksaan Payudara Sendiri pada lbu-ibu Peserta Pengajian 774 Harmayanti Khairun-Nisa di Taman Sari, Sragen, Skripsi, 2006.

9. Purwatiningsih W, Hubungan Pengetahuan tentang Kanker Payudara dengan Motivasi Penderita untuk Memeriksakan Diri secara Dini di Klinik Onkologi RSU dr. Soetomo, Surabaya, Buletin Penelitian RSUD dr. Soetomo, vol/no:11(1), 2009.

10. Handayani DS., Hubungan antara Tingkat Pengetahuan dan Sikap dengan Perilaku para Wanita Dewasa Awal dalam Melakukan Pemeriksaan Payudara Sendiri di Kelurahan Kalangan Kecamatan Pedan Klaten, Skripsi, Semarang: PSIK FK UNDIP, 2008. 
